\title{
Conflict between Pharmacy Preceptors and Pharmacy Learners in Experiential Education
}

\author{
Jennifer Kendrick, Arielle Beauchesne, Yunji Valerie Lee, Sue Corrigan, and Roxane Carr
}

Can J Hosp Pharm. 2021;74(1):36-42

\begin{abstract}
Background: The relationship between a preceptor and a learner is complex and can be prone to conflict. The issue of conflict in experiential education has been studied in medicine, nursing, social work, and education; however, conflict between pharmacy preceptors and learners has not been described.
\end{abstract}

Objective: To describe types of conflict between pharmacy preceptors and learners, the outcomes of such conflict, the impacts on the preceptor-learner relationship, and conflict-resolution strategies.

Methods: An anonymous electronic survey of pharmacist preceptors and pharmacy residents in British Columbia was conducted. The survey included various types of questions to enrich the quality of responses (e.g., Likert scale, ranking, and requests for comments). Descriptive statistics were used.

Results: Forty-nine participants completed the survey from the preceptor's perspective, 12 from the learner's perspective, and 4 from both perspectives. Sixty percent of preceptors (32/53) and $75 \%$ of learners (12/16) admitted experiencing conflict. Preceptors $(n=27)$ cited the learner's professionalism (74\%), knowledge/skills (59\%), communication issues (59\%), personal issues (56\%), and punctuality/ attendance $(52 \%)$ as causes of conflict. Learners, however $(n=12)$, cited differing expectations (67\%), teaching versus learning style preferences (50\%), and communication issues $(67 \%)$ as causes of conflict. The majority of preceptors and learners indicated that conflict had negatively affected the relationship; however, most preceptors (69\% [18/26]) and learners (50\% [6/12]) agreed or strongly agreed with the statement, "I have generally felt comfortable working with preceptors/learners after a conflict." More learners than preceptors felt that the learner's ability to perform was negatively affected by the conflict (92\% [11/12] versus 52\% [13/25]). Preceptors were more likely to take initiative to resolve conflict. Verbal communication was the method of conflict resolution preferred by both preceptors and learners. Most preceptors and learners indicated that they felt that conflicts were generally resolved.

Conclusions: Conflict was common in the pharmacy preceptor-learner relationship. Pharmacy preceptors and learners had different perspectives about the causes and outcomes of conflict.

Keywords: conflict, education, pharmacy, preceptorship, teaching

\section{RÉSUMÉ}

Contexte : La relation entre le précepteur et l'apprenant est complexe et peut entraîner des conflits. Le problème du conflit dans le domaine de l'éducation expérientielle a été étudié en médecine, en infirmerie, en travail social et en éducation; cependant, il n'existe aucune description des conflits entre les précepteurs et les apprenants en pharmacie.

Objectif : Décrire les types de conflits entre les précepteurs en pharmacie et les apprenants, les conséquences de tels conflits ainsi que les impacts sur la relation précepteur-apprenant et les stratégies de résolution de conflit.

Méthodes : Une enquête électronique anonyme a été menée auprès de précepteurs et de résidents en pharmacie en Colombie-Britannique. L'enquête comprenait diverses questions visant à enrichir la qualité des réponses (p. ex., échelle de Likert, classement et demandes de commentaires). L'étude s'appuie sur des statistiques descriptives.

Résultats : Quarante-neuf participants ont répondu à l'enquête en adoptant le point de vue du précepteur, 12 en adoptant celui de l'apprenant et 4 ont adopté le point de vue de l'apprenant et du précepteur. Soixante pour cent des précepteurs (32/53) et $75 \%$ des apprenants (12/16) ont admis traverser des conflits. Les sources de conflits citées par les précepteurs $(n=27)$ sont le professionnalisme de l'apprenant ( $74 \%$ ), les connaissances et compétences $(59 \%)$, les problèmes de communication ( $59 \%$ ), les problèmes personnels (56 \%) ainsi que la ponctualité et la présence (52\%). Quant aux apprenants $(n=12)$, ils ont cité des attentes divergentes $(67 \%)$, des préférences de style d'enseignement ou d'apprentissage (50\%) et des problèmes de communication (67\%) comme causes de conflit. La majorité des précepteurs et des apprenants ont indiqué que ces conflits avaient affecté la relation; cependant, la plupart des précepteurs (69\% [18/26]) et des apprenants (50\% [6/12]) étaient d'accord ou fortement d'accord avec l'énoncé suivant : « En général, je me suis senti à l'aise de travailler avec des précepteurs ou des apprenants après un conflit. » Un plus grand nombre d'apprenants que de précepteurs ont perçu que le conflit avait perturbé la capacité de I'apprenant (92 \% [11/12] par rapport à $52 \%$ [13/25]). Les précepteurs étaient plus enclins à faire preuve d'initiative pour résoudre le conflit. La communication verbale était la méthode de résolution de conflit préférée des précepteurs et des apprenants. La plupart des précepteurs et des apprenants ont indiqué ressentir que les conflits étaient généralement résolus.

Conclusions : Le conflit était répandu dans la relation précepteur et apprenant en pharmacie. Les précepteurs en pharmacie et les apprenants avaient différents points de vue sur les causes et les conséquences de ces conflits.

Mots-clés : conflits, éducation, pharmacie, préceptorat, enseignement 


\section{INTRODUCTION}

Experiential education plays a fundamental role in providing pharmacy learners with opportunities to acquire practical and clinical skills, and it assists in their transition to becoming health care professionals. ${ }^{1,2}$ Experiential education often consists of rotations or practicums, during which learners apply the knowledge and skills learned in the classroom to actual patient care environments, under the supervision of their preceptors. The preceptor-learner relationship is an important aspect of the learner's experience and allows the learner to receive direct feedback to improve their practice and their readiness to become an independent practitioner. ${ }^{2}$

Both preceptors and learners may face challenges in their roles. Preceptors must balance their responsibilities to patient care and to their learners. ${ }^{1}$ Learners are expected to apply knowledge and skills that they may or may not have been taught in the classroom. Learners must also assimilate into an unfamiliar environment and fulfill the expectations of the curriculum, as well as the expectations of the preceptor. ${ }^{2,3}$ The practicum experience may be their first time applying knowledge in the clinical setting and receiving feedback from a preceptor. The learner and preceptor must collaborate, yet given the preceptor's responsibilities and the learner's desire for success, their relationship is not immune to conflict. ${ }^{3}$

Conflict may be a learning opportunity for both preceptor and learner, but failure to address unresolved conflict can lead to dissatisfaction for both parties and create an uncomfortable learning environment. ${ }^{3}$ The preceptor-learner relationship has been described as a "significant, yet fragile liaison". 4 The issue of conflict in experiential education has been studied in medicine, nursing, social work, and education. ${ }^{5}$ Conflict results from differences in preceptor and learner expectations, intergenerational disagreement, and personality clashes. ${ }^{6,7}$ Conflict may facilitate or impede the learner's and/or preceptor's growth. ${ }^{6}$ Communication and feedback are suggested methods of conflict resolution, with or without the use of a mediator. ${ }^{3,6}$ Although preceptor-learner conflict has been studied in other health care disciplines, studies in pharmacy are lacking., ${ }^{5,7}$ Given the potential impact of conflict on the learning environment and the overall outcome of the rotation, we thought it important to study preceptor-learner conflict in the pharmacy setting. The goal of this study was to explore the types of conflict that arise between pharmacy preceptors and pharmacy residents from their respective perspectives. The objectives were to describe the types of conflict that occur, the outcomes of such conflict, the impact of conflict on the preceptor-learner relationship, and the strategies used for resolution of conflict.

\section{METHODS}

We developed an anonymous electronic survey using FluidSurveys (complete survey presented in Appendix 1, available at cjhp-online.ca/index.php/cjhp/issue/view/202). A pharmacist and a pharmacy learner who were not involved in the study tested the survey before distribution. Intended participants were hospital pharmacist preceptors and pharmacy residents in British Columbia. There are 5 Accredited Canadian Pharmacy Residency programs in our province, all of which offer rotations across multiple hospitals. Because the study was open to preceptors of all types of pharmacy learners, we allowed pharmacy learners other than residents to complete the survey (and included their data in the analysis) as a way to enrich the perspective of the learner. The survey questions were devised to help answer the research team's main questions: What types of conflict are prevalent? What have been the outcomes of such conflict? How has conflict influenced overall relationships and practicum experiences? Questions relating to conflict outcomes were based on the survey by Mamchur and Myrick. ${ }^{6}$ Participants had the option of completing the survey from the perspective of the preceptor, the perspective of the learner, or both (with current preceptors recalling their experiences as learners). Data provided by participants who answered from both perspectives were included in both analyses.

The survey used various methods of obtaining respondents' input, such as scaled questions, a 5-point Likert scale $(1=$ strongly disagree, $5=$ strongly agree $)$, ranking, availability of a comments section, and open-ended questions to enrich the quality of the response. The survey was designed to take 10 to 20 minutes to complete. For all questions, responses were optional. For cases in which the participant did not answer all survey questions, responses were reported and analyzed as provided (i.e., total number of respondents for a given question was indicated in the results, and percentages were calculated accordingly). The analysis included data only from surveys in which the participant answered the question, "Have you ever experienced conflict with a preceptor or learner?" The survey did not provide a definition of "conflict", and participants were left to answer questions according to their own definitions of this concept.

One member of the study team (R.C.) contacted pharmacy coordinators, pharmacy practice residency coordinators, and pharmacy residents in the province via email distribution lists in August 2017. Coordinators were also asked to distribute the survey to preceptors and residents. We estimated that 450 pharmacy preceptors and 40 pharmacy residents could have participated in the survey. Participants were given 8 weeks to complete the survey. No reminders were sent, because we used distribution lists and did not have email addresses for all potential participants.

This study was based on a sample size of convenience. Descriptive statistics were used for data analysis. For openended questions, 3 reviewers (J.K., A.B., R.C.) grouped responses into themes. Where there was disagreement, the reviewers planned to discuss the themes and come to a consensus; however, there were no disagreements. 
The study received ethics approval from the University of British Columbia - Children's and Women's Research Ethics Board.

\section{RESULTS}

Seventy-eight survey responses were received. Based on a total of 490 potential respondents, the response rate was $16 \%$. Thirteen surveys were excluded because the respondents did not answer the question, "Have you ever experienced conflict with a preceptor or learner?" Therefore, 65 surveys were included in the analysis (Table 1). Of those included, 49 participants answered from the preceptor's perspective,

\section{TABLE 1. Participant Characteristics}

\begin{tabular}{lcc} 
Characteristic & \multicolumn{2}{c}{$\begin{array}{c}\text { No. (\%) of } \\
\text { Participants } \\
(n=65)\end{array}$} \\
\hline Sex, female & 45 & $(69)$ \\
\hline Current pharmacy practice site & \multicolumn{2}{c}{$n=63$} \\
$\quad$ Hospital & 58 & $(92)$ \\
Residential care & 1 & $(2)$ \\
Ambulatory clinic & 4 & $(6)$ \\
Current pharmacy learner program & \multicolumn{2}{c}{$n=11$} \\
$\quad$ Residency & 8 & $(73)$ \\
Undergraduate pharmacy & 1 & $(9)$ \\
PharmD & 2 & $(18)$ \\
Learner experience & \multicolumn{2}{c}{$n=16$} \\
$\quad$ No. of practicums (median and range) & $7.5 \quad(2-24)$ \\
No. of preceptors (median and range) & 9 & $(2-28)$ \\
Preceptor experience & \multicolumn{2}{c}{$n=53$} \\
No. of years as a preceptor (median and range) & 6 & $(1-25)$ \\
No. of learners per year (median and range) & 2 & $(1-20)$ \\
\hline
\end{tabular}

12 from the learner's perspective, and 4 from both perspectives. The majority of learners were pharmacy residents, and the majority of preceptors worked in the hospital setting. Preceptors $(n=53)$ indicated they had experience working in this role with pharmacy residents $(83 \%)$, undergraduate pharmacy students (94\%), entry-to-practice PharmD students (32\%), and postbaccalaureate PharmD students (32\%). Thirty-two preceptors (60\%) and 12 learners (75\%) reported having experienced conflict with a learner or a preceptor, respectively. The median percentage of relationships in which preceptors and learners had experienced conflict was $12.5 \%$ and $19.4 \%$, respectively. None of the preceptors reported having had to withdraw from their role as a preceptor because of conflict with a learner; however, 17 (32\%) of them reported that conflict with a learner had affected their willingness to serve as a preceptor for new learners in the future. The majority of preceptors indicated that they had experienced conflict with learners equally throughout their career (Table 2).

\section{Types of Conflict}

Participants identified a variety of issues that had led to preceptor-learner conflict in their relationships (Figure 1). Among preceptors, the most frequent causes of conflict and the most stressful causes of conflict were the learner's professionalism and the learner's knowledge/skills, and the learner's professionalism and the learner's personal issues were the most challenging to address (Table 3 ). In contrast, learners cited different expectations and differences in teaching versus learning styles as the most frequent causes of conflict, different expectations and personality conflict as the most stressful causes of conflict, and personality conflicts as the most challenging to address (Table 3 ). A greater proportion of preceptors reported having experienced the same type of conflict with multiple learners (58\% [15/26]) than learners reported experiencing with multiple preceptors $(25 \%[3 / 12])$.

\section{TABLE 2. Characteristics of Conflicts}

Group; No. (\%) of Participants ${ }^{a}$

\begin{tabular}{|c|c|c|c|c|}
\hline \multirow{2}{*}{$\begin{array}{l}\text { Characteristic } \\
\% \text { of relationships with conflict (median and range) }\end{array}$} & \multicolumn{2}{|c|}{ Preceptors $(n=32)$} & \multicolumn{2}{|c|}{ Learners $(n=12)$} \\
\hline & 12.5 & $(4.5-66.7)$ & 19.4 & $(5.9-100)$ \\
\hline When conflict has been experienced & \multicolumn{2}{|c|}{$n=29$} & \multicolumn{2}{|c|}{ NA } \\
\hline As a new preceptor & 4 & (14) & & \\
\hline As a veteran preceptor & 4 & (14) & & \\
\hline Equally throughout career & 21 & $(72)$ & & \\
\hline Most frequent occurrence of conflict & \multicolumn{2}{|c|}{$n=26$} & \multicolumn{2}{|c|}{$n=12$} \\
\hline Daily & 7 & $(27)$ & 4 & (33) \\
\hline Weekly & 13 & $(50)$ & 4 & (33) \\
\hline Every few weeks & 0 & $(0)$ & 2 & (17) \\
\hline Once per rotation & 6 & $(23)$ & 2 & (17) \\
\hline
\end{tabular}

${ }^{\mathrm{a}}$ Except where indicated otherwise. 
In response to an open-ended question asking participants to describe the worst conflict they had experienced, preceptors $(n=23)$ generally responded that these conflicts arose because of issues with the learner's professionalism, such as poor attitude, refusal to take initiative, unwillingness to participate in rotation activities, provision of inaccurate information to colleagues and patients, reluctance to accept suggestions/feedback, failure to meet deadlines, and poor attendance. Poor knowledge base or performance was less frequently cited. In response to the same question about the worst conflict they had experienced, learners $(n=10)$ responded that these conflicts had been due to differences in teaching versus learning style, a preceptor appearing disinterested or misjudging the learner, and lack of transparency

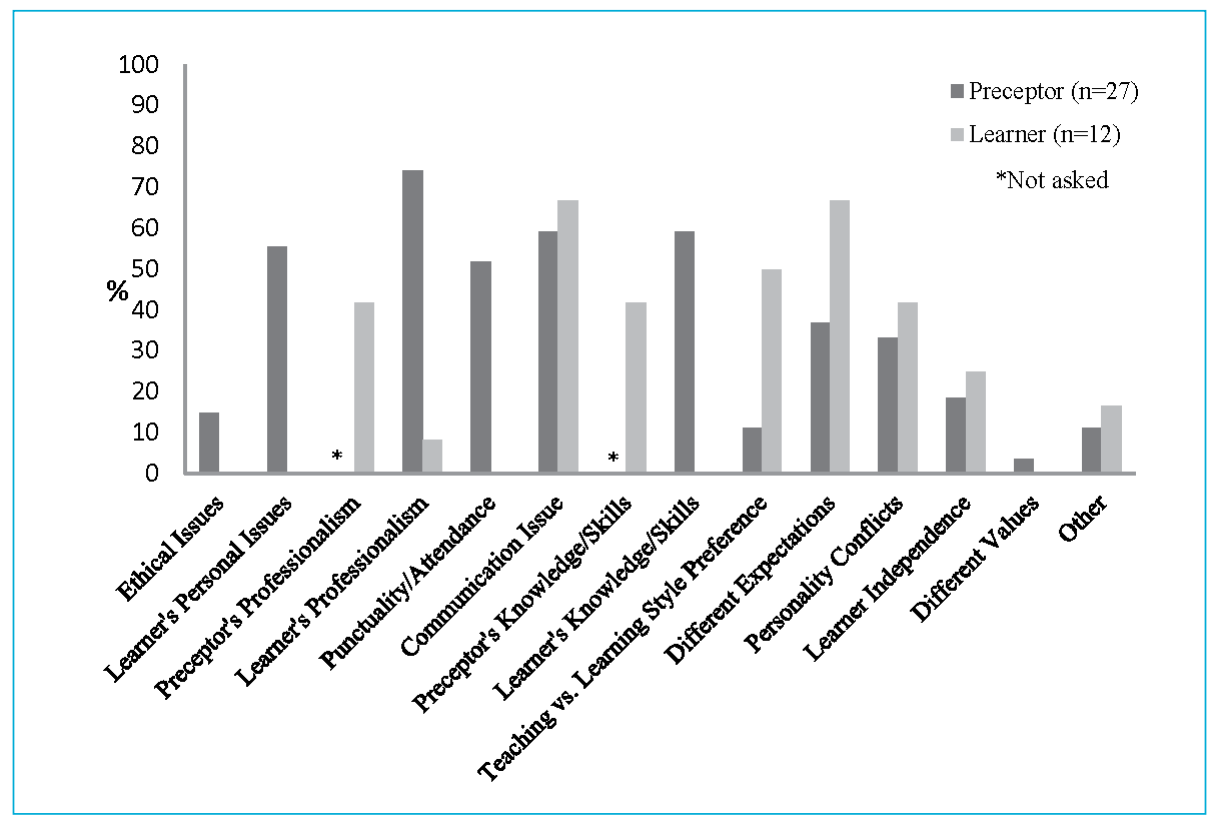

FIGURE 1. Causes of conflict between preceptors and learners.

TABLE 3. Causes of Conflict between Preceptors and Learners Reported as Most Frequent, Most Stressful, and Most Challenging to Address, Reported as Number (\%) of Each Group

\begin{tabular}{|c|c|c|c|c|c|c|c|c|c|c|c|c|}
\hline \multirow{3}{*}{$\begin{array}{l}\text { Issues } \\
\text { Ethical issues }\end{array}$} & \multicolumn{4}{|c|}{ Most Frequent } & \multicolumn{4}{|c|}{ Most Stressful } & \multicolumn{4}{|c|}{ Most Challenging to Address } \\
\hline & \multicolumn{2}{|c|}{$\begin{array}{l}\text { Preceptors } \\
(n=27)\end{array}$} & \multicolumn{2}{|c|}{$\begin{array}{l}\text { Learners } \\
(n=12)\end{array}$} & \multicolumn{2}{|c|}{$\begin{array}{c}\text { Preceptors } \\
(n=27)\end{array}$} & \multicolumn{2}{|c|}{$\begin{array}{l}\text { Learners } \\
(n=12)\end{array}$} & \multicolumn{2}{|c|}{$\begin{array}{c}\text { Preceptors } \\
(n=27)\end{array}$} & \multicolumn{2}{|c|}{$\begin{array}{l}\text { Learners } \\
(n=12)\end{array}$} \\
\hline & 0 & & 0 & & 3 & (11) & 0 & & 1 & (4) & 0 & \\
\hline Learner's personal issues & 1 & (4) & 0 & & 3 & (11) & 0 & & 6 & $(22)$ & 0 & \\
\hline Preceptor's professionalismª & - & & 1 & (8) & - & & 0 & & - & & 2 & (17) \\
\hline Learner's professionalism & 10 & (37) & 0 & & 6 & (22) & 0 & & 6 & (22) & 0 & \\
\hline Punctuality/attendance & 2 & (7) & 0 & & 2 & (7) & 0 & & 1 & (4) & 0 & \\
\hline Communication issues & 1 & (4) & 0 & & 2 & (7) & 1 & (8) & 0 & & 0 & \\
\hline Learner's knowledge/skills & 7 & $(26)$ & 1 & (8) & 4 & (15) & & $(17)$ & 4 & (15) & 1 & (8) \\
\hline $\begin{array}{l}\text { Teaching versus learning style } \\
\text { preference }\end{array}$ & 0 & & 3 & $(25)$ & 0 & & 1 & (8) & 0 & & 1 & (8) \\
\hline Different expectations & 3 & (11) & 5 & $(42)$ & 3 & (11) & 3 & $(25)$ & 3 & (11) & 1 & (8) \\
\hline Personality conflicts & 1 & (4) & 0 & & 2 & (7) & 3 & $(25)$ & 3 & (11) & 4 & (33) \\
\hline Learner independence & 0 & & 0 & & 0 & & 0 & & 2 & (7) & 1 & (8) \\
\hline Other & 2 & (7) & 2 & (17) & 2 & (7) & 2 & (17) & 1 & (4) & 2 & (17) \\
\hline
\end{tabular}

aDash indicates that the question was not asked for this category of participant. 
about progress or standing in the rotation. The conflict scenarios described had negative outcomes for the learner, the preceptor, or the relationship. Learners often described these most difficult conflicts as being unresolved.

\section{Impact of Conflict on the Preceptor-Learner Relationship}

When asked about the outcomes of conflicts, the majority of preceptors and learners indicated that there were negative effects on the relationship (Figure 2). At least half of preceptors $(69 \%)$ and learners (50\%) agreed or strongly agreed with the statement, "I have generally felt comfortable working with preceptors/learners after a conflict"; however, a larger proportion of learners than preceptors disagreed or strongly disagreed with this statement (25\% versus $8 \%$ ).

\section{Outcomes of Conflict}

Preceptors indicated that conflict had facilitated learner's growth, whereas learners indicated that conflict impeded their growth (Figure 2). Few preceptors and learners indicated that conflict had been detrimental to their image or had affected their personal health. More learners than preceptors agreed or strongly agreed with the statement, "I felt that the learner's/my ability to perform was negatively impacted by the conflict" (92\% [11/12] versus 52\% [13/25]).
When asked what outcomes had arisen from the worst conflict, responses were similar to those in Figure 2, except that more preceptors and learners indicated that the learner's health had been compromised.

\section{Conflict Resolution}

More preceptors than learners reported that they "frequently" or "always" took initiative to resolve conflict (69\% [18/26] versus 17\% [2/12]). Forty-six percent (12/26) of preceptors agreed or strongly agreed with the statement, "I have generally felt comfortable addressing conflict with learners", whereas 35\% (9/26) disagreed or strongly disagreed. Fifty percent (6/12) of learners agreed or strongly agreed with the statement, "I generally felt comfortable with the way preceptors addressed conflict with me", and 17\% $(2 / 12)$ disagreed or strongly disagreed. When learners were asked about resolving conflict, $67 \%$ (8/12) agreed or strongly agreed with the statement, "It is better to just 'grin and bear it' when conflict arises."

With respect to methods used to resolve conflict, as reported by 26 preceptors, the majority of preceptors reported having used verbal communication $(100 \%)$ or having involved another pharmacist/preceptor (65\%) or the program facilitator/mediator (54\%). Fewer of these preceptors reported using written communication $(27 \%)$ or involving

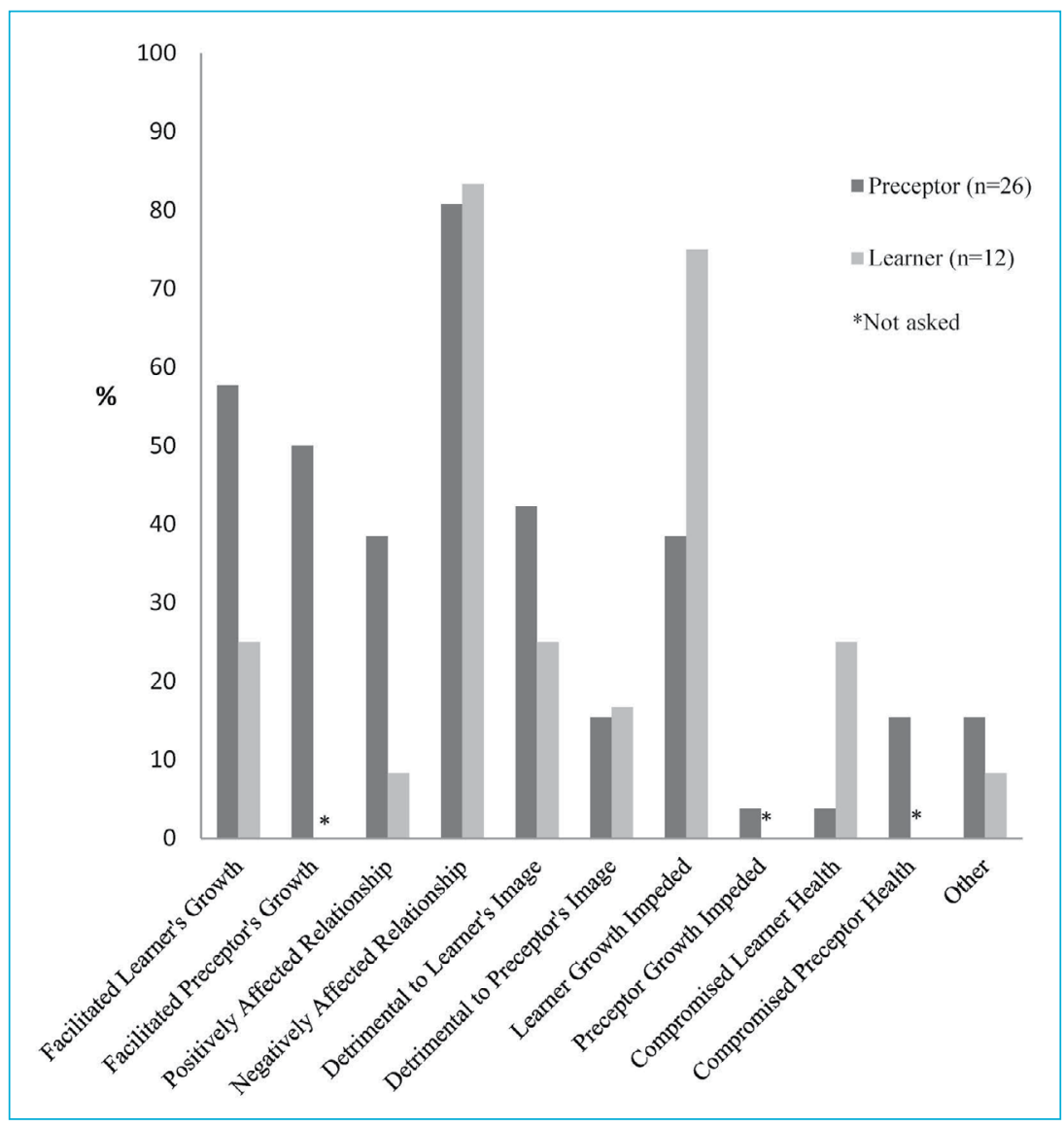

FIGURE 2. Outcomes of conflict between preceptors and learners. 
their supervisor $(35 \%)$ or the program director/coordinator $(38 \%)$. Preceptors found verbal communication to be the most effective strategy (65\% [17/26), and learners were most comfortable with this method (58\% [7/12]). Preceptors and learners also cited involving another pharmacist or a program facilitator or director as a preferred method for conflict resolution. Large proportions of preceptors $(n=26)$ and learners $(n=12)$ indicated their perception that conflicts were resolved either frequently ( $42 \%$ in both groups) or sometimes ( $54 \%$ and $50 \%$, respectively).

\section{DISCUSSION}

In this survey study, large proportions of preceptors and learners reported ever having experienced conflict; however, conflict occurred in less than $20 \%$ of relationships. In contrast, Mamchur and Myrick ${ }^{6}$ surveyed preceptors and learners from medicine, nursing, social work, and education and found that $25 \%$ of preceptors and $32 \%$ of learners reported ever experiencing conflicts in their relationships. The prevalence ranged from $17 \%$ to $50 \%$ depending on the profession and the perspective of learner versus preceptor in that study; both preceptors and learners in family medicine reported the highest incidence of conflict. ${ }^{6}$ The higher prevalence in our study may be due to preceptors and learners who had experienced conflict being more likely to participate in the survey or may be related to differences between professions.

Mamchur and Myrick $^{6}$ found that the majority of learners listed expectations of the preceptor and personal/ personality issues with the preceptor as causes of conflict, whereas preceptors listed expectations of the preceptor, expectations of the student, student knowledge, and student skill as causes of conflict. In other qualitative studies about preceptor-learner conflict, participants described personality conflict, different expectations, knowledge, and skills as themes causing conflict. ${ }^{5,7}$ Reported disparities between preceptors' and learners' perceptions about the causes of conflict are common regardless of the health care profession. ${ }^{5-7}$ In our study, we also found disparity between preceptors' and learners' perceptions of causes of conflict, as well as what they reported to be the most frequent, stressful, and difficult to address causes of conflict. In our survey, we did not define conflict for the respondent; therefore, preceptors and learners might have had different perspectives of what constitutes conflict. Additionally, preceptors and learners may have different perspectives on their respective roles in conflict. The majority of preceptors and learners reported communication issues as a cause of conflict. Learners reported issues with different expectations and differences in teaching versus learning styles causing conflict. Professionalism was described by preceptors as one of the most frequent and most stressful causes of conflict and the most difficult type of conflict to address. This may relate to difficulty in defining what specific behaviours are to be evaluated within "professionalism" or, possibly, to pharmacists having heightened awareness because of attention to professionalism in pharmacy curricula in recent years. ${ }^{8}$ Professionalism, like conflict, can be difficult to define, as there is little consensus in the literature. ${ }^{9}$ The Canadian Pharmacy Residency Board, for example, requires pharmacy residents to hold high professional ideals, such as being committed to continued learning and improvement, using constructive feedback, exhibiting professional behaviours and relationships, and demonstrating a commitment to excellence. ${ }^{10}$

Similar to what was reported by Mamchur and Myrick, ${ }^{6}$ preceptors in our study had a more positive outlook on the outcomes of conflict than did learners. It is possible that preceptors recognize conflict as an important learning experience, whereas learners view it as detrimental to their learning and self-esteem, and fail to see the value of practising conflict resolution. The real or perceived power differential between preceptor and learner may also play a role, including fears of negative consequences. This may relate to our findings that few learners reported taking the initiative to resolve conflict and more than two-thirds of learners agreed with the statement that it is better to just "grin and bear it" when conflict arises. These results concurred with those of Myrick and others, ${ }^{5}$ who surveyed learners in the disciplines of medicine, nursing, social work, and education in relation to preceptor-learner conflict. Many participants in that study stated that they felt the best course of action was to remain silent, rather than to make attempts at resolution of conflict. Being able to resolve conflict in a respectful manner and being able to provide effective and constructive feedback are aspects of professionalism. ${ }^{8}$

Most participants in our study reported the perception that conflicts were frequently or sometimes resolved, which is similar to findings for other professions. ${ }^{6}$ Although both preceptors and learners indicated that conflict negatively affected the relationship, both groups generally felt comfortable working with one another afterward. Our use of mostly closed-ended questions did not allow us to explore the relationship between the extent to which conflict was addressed and resolved and the impact on the preceptor-learner relationship. In response to our open-ended question asking participants to describe the worst conflict they had experienced, the learners' narratives often described the conflict as both having a negative outcome and being unresolved.

Given the prevalence of conflict and the potential negative outcomes in preceptor-learner relationships, increasing awareness and incorporating conflict-resolution training would be important for both preceptors and learners. Some preceptor training programs incorporate case-based scenarios or discussions to address conflict resolution. ${ }^{3,11}$ Emotionally intelligent behaviours, such as reflection, reframing, controlling discomfort, and expressing emotions appropriately, have been described by pharmacy and nursing students as helpful in managing conflict during clinical placements. ${ }^{12}$ 
With most learners being reluctant to address conflict and their perceptions of the causes of conflict being different from those of preceptors, it is possible that many conflicts go unnoticed by preceptors. Given that conflict resolution is an aspect of professionalism, developing skills in conflict resolution through both didactic and experiential learning may be helpful for learners. Increasing awareness of learners' perceptions of conflict may allow preceptors to assist learners in addressing and resolving conflict.

The main limitation of this study was the low response rate. We estimated that up to 450 hospital-based pharmacist preceptors and 40 pharmacy residents could have responded to our survey; however, the exact number of potential participants who received the invitation to participate in the study is unknown. There may have been selection bias, with preceptors and learners who experienced conflict being more likely to respond to the survey. We also focused on hospital-based programs, so our findings may not reflect the experiences of preceptors and learners in community or ambulatory-based programs. Given the nature of our study design, we were unable to explore specific conflicts that occur within a preceptor-learner relationship or how conflict changes over time.

\section{CONCLUSION}

Conflict within the pharmacy preceptor-learner relationship was common among participants in our survey; however, preceptors and learners had different perspectives about the causes of conflict. Learners frequently reported that conflict had negative outcomes, whereas preceptors identified that professional growth and skill development can result from conflict. Preceptors indicated that they took the initiative to resolve conflict but were not necessarily comfortable doing so.

\section{References}

1. Hartzler ML, Ballentine JE, Kauflin MJ. Results of a survey to assess residency preceptor development methods and precepting challenges. Am J Health Syst Pharm. 2015;72(15):1305-14.

2. Davis LE, Miller ML, Raub JN, Gortney JS. Constructive ways to prevent, identify, and remediate deficiencies of "challenging trainees" in experiential education. Am J Health Syst Pharm. 2016;73(13):996-1009.

3. Phillips H, Fuller PD, May JR, Johnston S, Pettit NN. Conflict resolution strategies between preceptor and resident-a case-based scenario. Am J Health Syst Pharm. 2014;71(3):184-6.

4. Sawa R. Teaching caring in conflicted systems: field placement teaching in family medicine. In: Rogers G, editor. Social work field education: views and visions. Kendall/Hunt; 1995. p. 510-22.
5. Myrick F, Phelan A, Barlow C, Sawa R, Rogers G, Hurlock D. Conflict in the preceptorship or field experience: a rippling tide of silence. Int $J$ Nurs Educ Scholarsh. 2006;3(1):1-14.

6. Mamchur C, Myrick F. Preceptorship and interpersonal conflict: a multidisciplinary study. J Adv Nurs. 2003;43(2):188-96.

7. Foley V, Myrick F, Yonge O. Intergenerational conflict in nursing preceptorship. Nurse Educ Today. 2013;33(9):1003-7.

8. Eukel H, Frenzel J, Skoy E, Faure M. Longitudinal evaluation of student professionalism throughout the professional didactic curriculum of a pharmacy program. Cur Pharm Teach Learn. 2018;10(3):325-32.

9. Dubbai H, Adelstein BA, Taylor S, Shulruf B. Definition of professionalism and tools for assessing professionalism in pharmacy practice: a systematic review. J Educ Eval Health Prof. 2019;16:22.

10. Canadian Pharmacy Residency Board. Accreditation standards for pharmacy (year 1) residencies. Canadian Society of Hospital Pharmacists; 2018 [cited 2020 May 4]. Available from: https://www.cshp.ca/ sites/default/files/residency/CPRB\%20Pharmacy\%20(Year\%201)\%20 Residency\%20Standards\%20-\%20FINAL\%20(06May2018).pdf

11. Jung CM, Ansara ED, Degenkolb KE, Walroth TA, Williams KE. Development of a precepting workshop for pharmacy residents. Am J Health Syst Pharm. 2016;73(3):127-32.

12. McCloughen A, Foster K. Nursing and pharmacy students' use of emotionally intelligent behaviours to manage challenging interpersonal situations with staff during clinical placement: a qualitative study. JClin Nurs. 2018;27(13-14):2699-709.

Jennifer Kendrick, BSCPharm, ACPR, PharmD, is with the Pharmacy Department, Children's and Women's Health Centre of $B C$, and the Faculty of Pharmaceutical Sciences, The University of British Columbia, Vancouver, British Columbia.

Arielle Beauchesne, PharmD, ACPR, was, at the time of this study, a student in the Faculty of Pharmaceutical Sciences, The University of British Columbia, Vancouver, British Columbia. She is now a Year 2 Resident with Lower Mainland Pharmacy Services.

Yunji Valerie Lee, BScPharm, ACPR, was, at the time of this study, a Pharmacy Resident with Lower Mainland Pharmacy Services. She is now a Clinical Pharmacist with the Pharmacy Department of Providence Health Care, Vancouver, British Columbia.

Sue Corrigan, BSCPharm, ACPR, PharmD, was, at the time of this study, the Residency Coordinator for Lower Mainland Pharmacy Services. She is now with the Pharmacy Department, Eagle Ridge Hospital, Port Moody, British Columbia, and retains her position with the Faculty of Pharmaceutical Sciences, The University of British Columbia, Vancouver, British Columbia.

Roxane Carr, BScPharm, ACPR, PharmD, is with the Pharmacy Department, Children's and Women's Health Centre of BC, and the Faculty of Pharmaceutical Sciences, The University of British Columbia, Vancouver, British Columbia.

Competing interests: None declared.

Address correspondence to:

Dr Jennifer Kendrick

Pharmacy Department

Children's and Women's Health Centre of $B C$

Room 0B7, 4500 Oak Street

Vancouver BC V6H 3N1

email: Jennifer.Kendrick@cw.bc.ca

Funding: None received. 